\title{
The density, composition and mangrove forest habitat in coastal areas of Torosiaje Jaya Village, Gorontalo, Indonesia
}

\author{
SUKIRMAN RAHIM ${ }^{1, \bullet}$, DEWI WAHYUNI K. BADERAN ${ }^{2, \bullet \bullet}$, MARINI SUSANTI HAMIDUN ${ }^{3, \bullet}$ \\ ${ }^{1}$ Department of PGSD, Faculty of Education, Universitas Negeri Gorontalo. Jl. JendralSudirman 6, Kota Gorontalo, Gorontalo, Indonesia. ^email: \\ sukirmanrahim@yahoo.co.id \\ ${ }^{2}$ Department of Biology, Faculty of Mathematics and Natural Sciences, Universitas Negeri Gorontalo. Jl. JendralSudirman 06, Kota Gorontalo, \\ Gorontalo, Indonesia. Tel./Fax.+0435-821752,^»email: dewibaderan14@gmail.com, ^»marinish70@gmail.com
}

Manuscript received: 21 March 2017. Revision accepted: 29 June 2017.

\begin{abstract}
Rahim S, Baderan DWK, Hamidun MS. 2017. The density, composition and mangrove forest habitat in coastal areas of Torosiaje Jaya Village, Gorontalo, Indonesia. Bonorowo Wetlands 7: 38-42. The mangrove ecosystem is quite good, located in Torosiaje Jaya Village of Popayato Subdistrict, Pohuwato District, Gorontalo Province, Indonesia. This is because the beach in the coastal of Torosiaje Jaya Village is gently sloping; this beach has deposited sediment. A promontory grave is formed that causes the mangrove in that region to grow large and relatively fertile. In addition, the mangrove, which is located in Pohuwato, has relatively high various species. One of them is found from the Avicenniaceae family, namely the Avicennia marina (Forsk.) Vierh. This study aims to (i) obtain the information about the density of the mangrove; (ii) to determine the composition of mangrove species in coastal areas of Torosiaje Jaya Village; and (iii) to know the habitat of the species which is found in coastal areas Torosiaje Jaya Village. Besides, the data were collected by purposive sampling. Moreover, for measuring density, distribution type, diameter trees, and mangrove vegetation height, use a distance method (Point-Centered Quarter Method). Further, the composition types of views are based on the number of species found. To obtain the data of the habitat conditions of the species discovered using direct observation in the field by a tree and laboratory test sample originating from soil samples in the study sites. Moreover, this study finds the four tree species that dominate the mangrove in Torosiaje Jaya Village. They are Bruguiera gymnorrhiza, Rhizophora mucronata, Rhizophora apiculata, and Rhizophora stylosa with a density value of 51.55 trees/3 ha with an average distance of $581.94 \mathrm{~m} /$ tree. B. gymnorrhiza and $R$. mucronata dominate in the region due to supply mud as a suitable habitat for its growth; besides, the substrate of mangroves in the Torosiaje Jaya Village is also affected by salinity and temperature. Further, the data obtained can be used to manage mangrove forests located in the coastal of Torosiaje Jaya Village. They can also be data in mangrove conservation efforts to reduce the effects of global warming.
\end{abstract}

Keywords: Composition, density, habitat, mangrove forests

\section{INTRODUCTION}

Mangrove forests have a role in mitigating climate change due to global warming. They can reduce $\mathrm{CO}_{2}$ through the sequestration mechanism that carbon sequestration from the atmosphere and storage in several compartments such as vegetation, litter, and soil organic matter (Hairiah and Rahayu 2007). Through photosynthesis, the mangrove plants absorb carbon dioxide from the atmosphere and are converted into organic carbon distributed to all body parts and stored in the biomass plant. According to Nugraha (2011), about 50\% of tree biomass is carbon.

One of the mangrove areas in Indonesia is in the coastal region of Gorontalo Province, Torosiaje Jaya Village of Pohuwato region. Pohuwato is a famous green belt of mangrove and coastal ecosystems where the mangrove is broad enough to stretch from the District of Paguat until Popayato District of West. Mangrove areas have contained in Pohuwato relatively high species diversity. One of the mangrove species found, among others, from the family Avicenniaceae, namely Avicennia marina (Forsk.) Vierh. According to Dharmawan and Siregar (2008), A. marina is one of the mangrove species that can absorb and store carbon because of the habitat characteristic of wetlands with muddy soil types.

Based on the results of interpretation of Landsat imagery reported by Damanik (2012), the mangrove area Pohuwato has undergone significant changes, which in 1988 reached the mangrove area of 13243.33 hectares, in 2010 the remaining 7420.73 ha. The damage to the mangrove forests in the coastal Torosiaje Jaya Village impacts other Tomini bay ecosystem conditions such as Togean Islands National Park in Tojo Una-Una, Central Sulawesi Province. By reducing the coastal mangrove area in Torosiaje Jaya Village cause of carbon in the atmosphere cannot be absorbed and stored in plant biomass optimally. This further confirms the need for a precautionary measure to damage that occurred in the coastal mangrove Torosiaje Jaya Village needs to be immediately addressed through the information on the density, composition, and habitat of mangrove forests. The findings of this research may serve as a database for mangrove forest conservation management purposes in Torosiaje and other regions and for addressing global warming and climate change issues. 


\section{MATERIALS AND METHODS}

\section{Study area}

The study area is located in the coastal areas of mangrove forest Torosiaje Jaya Village, Popayato Subdistrict, Pohuwato District, Gorontalo Province, Indonesia (N $\left.0^{\circ} 28^{\prime} 45^{\prime \prime} \mathrm{E}, 121^{\circ} 26^{\prime} 15^{\prime \prime}\right)$. The geographical position of the study area is presented on the map (Figure 1).

\section{Methods}

The method used in this research is using the quadrant method or P-CQM (Point Centered Quarter Method). Each plant is contained in the quadrant, recorded the species' name (as seen by recognition by the research team and mangrove identification books (Tomlinson 1986; Giesen et al. 2006). The tree's diameter is measured based on diameter at breast height $(\mathrm{dbh})$ of $1.3 \mathrm{~m}$ above the ground or above the buttresses. In contrast, the total tree height is calculated from the above buttress without counting the canopy.

The stages will be undertaken in this study are: (i) The preparation phase, covering: observation, setting up data collection methods, and preparing the equipment used for data collection in the field. (ii) The data collection stage includes determining the density of vegetation.

To determine the density of the vegetation at the study site, created transect lines perpendicular to the shoreline landward by determining the point of observation or sampling point along the transect. At every point of measurement is made abscissa and imaginary ordinate line, so that at each measurement point there are four quadrants: I, II, III, and IV. Select one of the trees in each quadrant located closest to the end of a benchmark tree and measure the distance from each tree to the tree point benchmark.

Each plant is contained in the quadrant and recorded the species' name. The tree's diameter is measured based on diameter at breast height ( $\mathrm{dbh}$ ) of $1.3 \mathrm{~m}$ above the ground or above the buttresses. In contrast, the total tree height is calculated from the above buttress without counting the canopy; furthermore, in calculating the density of the wood. Mangrove species that cannot be identified in the field were taken, for instance, leaves, fruits, and flowers to be made herbarium and further identified in the Laboratory of Botany, Universitas Negeri Gorontalo, Indonesia. In addition to data mangrove species, also measured the temperature, salinity, soil $\mathrm{pH}$, and moisture.
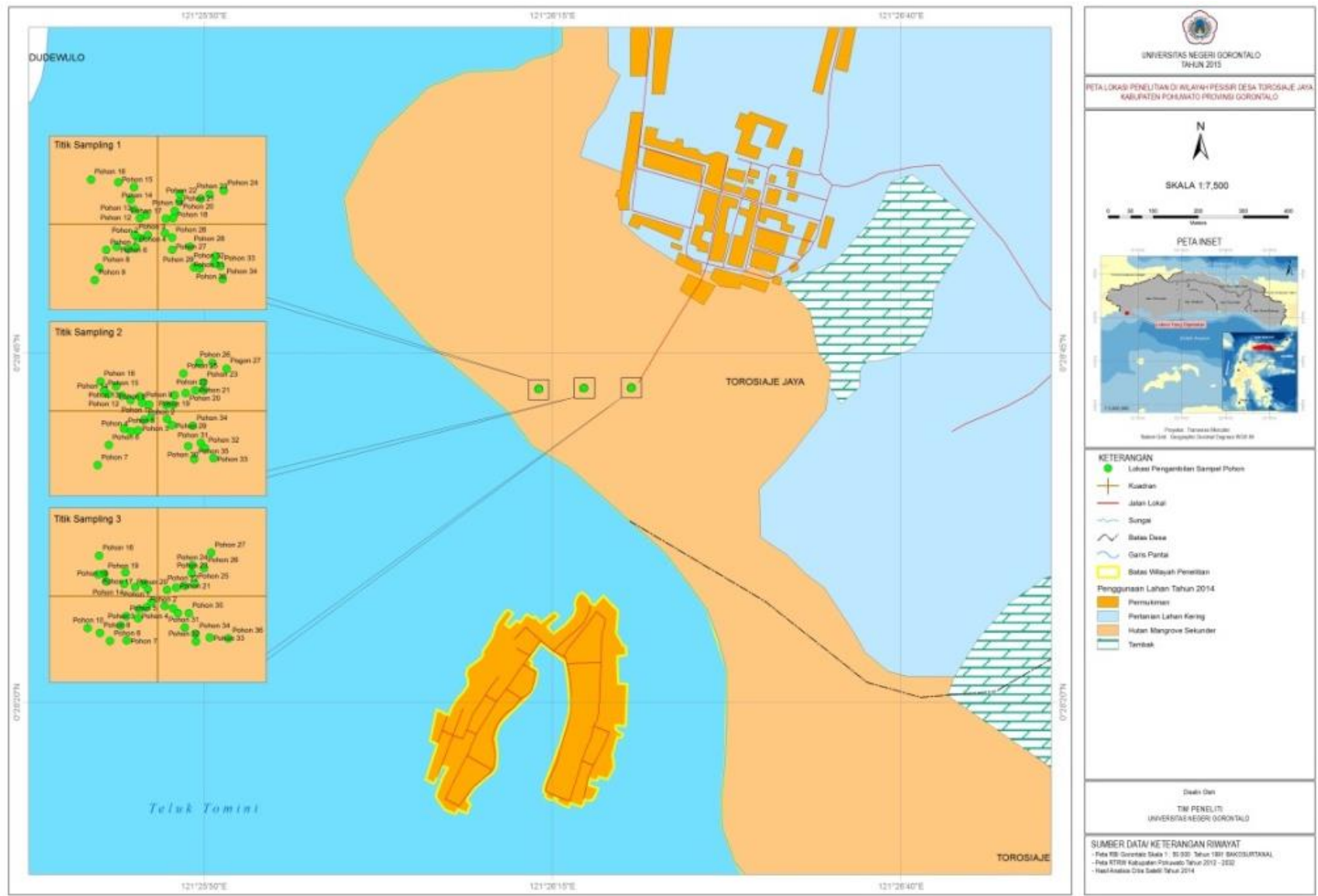

Figure 1. The study site in the coastal region of Torosiaje Jaya Village, Gorontalo, Indonesia 


\section{Data analysis}

Density

To calculate the density, calculated the average distance of each individual tree with the following formula (Indriyanto 2010):

The distance of the average individual tree to tree points benchmark (d):

$$
\mathrm{d}=\frac{\mathrm{d} 1+\mathrm{d} 2+\mathrm{d} 3+\cdots+\mathrm{dn}}{\mathrm{n}}
$$

Where:

$\mathrm{d} 1, \mathrm{~d} 2, \mathrm{~d} 3, \ldots \ldots \ldots, \mathrm{dn}=$ distance of each tree to the point of measurement

$\mathrm{n}=$ number of trees

$\mathrm{d}=$ average distance of individual trees to the measuring point

\section{The density of all species per hectare $(K)$}

To calculate the density of all types of trees using the following formula (Indriyanto 2010):

$$
\mathrm{k}=\frac{\text { Area }}{(\text { average distance of tres })^{2}}
$$

\section{Volume of trees}

The volume of trees is the content or the magnitude of a sample obtained from the width and height of the sample. Tree volume calculated using the formula Brown (1997):

$$
\mathrm{V}=1 / 4 \cdot \pi \cdot \mathrm{d}^{2} . \mathrm{t} \cdot \mathrm{f}
$$

$$
\begin{aligned}
& \text { Where: } \\
& \mathrm{V}=\text { volume of trees }\left(\mathrm{m}^{3}\right) \\
& \begin{array}{l}
\pi=\text { constant }(3.14) \\
\mathrm{d}=\text { diameter of tree height chest }(\mathrm{cm}) \\
\mathrm{t}=\text { total height }(\mathrm{m}), \text { and } \\
\mathrm{f}=\text { figures tree form }(0.6)
\end{array}
\end{aligned}
$$

\section{Composition type}

Composition kind is calculated based on the number of mangrove species are found.

\section{Habitat}

The research used descriptive analysis towards the habitat analysis obtained from the soil sample analysis done in the laboratory. The laboratory examination included soil texture (sand, silt, and clay). In addition, the research also covered temperature, humidity, and salinity aspects, which are significant factors in the development of mangroves.

\section{RESULTS AND DISCUSSION}

\section{Results}

Density, the density of all species per hectare, and tree volume

The density of trees in the Torosiaje Jaya Village indicates a density value of 51.55 trees/3 ha with an average distance of $581.94 \mathrm{~m} /$ tree. All species density values were presented in (Table 1)

\section{Composition type}

In Table 2, it can be argued that in the mangrove forest Torosiaje Jaya Village number of species found little that four types,i.e., Bruguiera gymnorrhiza, Rhizophora mucronata, Rhizophora apiculata, dan Rhizophora stylosa, of trees 36 individual per $300 \mathrm{~m}^{2}$ with an average distance of 581,94 (trees/3 ha). The number of trees in sampling points $300 \mathrm{~m}^{2}$ in the village of Mangrove Forests Torosiaje Jaya, Gorontalo, Indonesia, is presented in Table 2 below.

\section{Habitat for mangrove species}

Texture, detritus, and $\mathrm{pH}$ are the dominant factors that affect the development of mangroves. Mangrove soil is alluvial, which is brought and sedimented by the river and seawater. Alluvial can be classified as sand, silt, and clay. It is these three components that form soil in different compositions. Mud is composed of silt and clay, which are rich in detritus.

The analysis conducted at the Laboratory of PG Tolangohula and the site investigation revealed that the habitat of the species found in Torosiaje for Sampling Point 1, Bruguiera gymnorrhiza is in the habitat which contains sand (0\%), silt (61.0-62.1\%), and clay (38.9-39.0\%). Sampling Point 2, Rhizophora mucronata contains sand $(0 \%)$, silt $(62.5-69.7 \%)$, and clay $(30.8-37.5 \%)$. Sampling Point 3, the habitat of Rhizophora stylosa contains sand $(0 \%)$, silt $(52.0 \%)$, and clay $(47.0 \%)$. The habitat of Rhizophora apiculate contains sand (0\%), silt (33.4\%), and clay $(67.0 \%)$. The temperature at Sampling Point 1 for Bruguiera gymnorrhiza ranges between $31.5-31.8^{\circ} \mathrm{C}$, its salinity is between $21.6 \mathrm{ppt}-22.1 \mathrm{ppt}$ and its humidity level is between $84.8-85 \%$. At Sampling Point 2, the temperature for Rhizophora mucronata ranges between 31$31.5^{\circ} \mathrm{C}$, its salinity is between $21.8-22.1 \mathrm{ppt}$, and its humidity level is between $85-86 \%$. At the Sampling Point 3 , the temperature for Rhizophora apiculate ranges between $30-30.5^{\circ} \mathrm{C}$, its salinity is between $21.2-21.8 \mathrm{ppt}$, and its humidity level is between $86.5-87 \%$; the temperature for Bruguiera gymnorrhiza is $30^{\circ} \mathrm{C}$, its salinity is $20.5 \mathrm{ppt}$, and its humidity level is $87 \%$; the temperature for Rhizophora stylosa is $30.5^{\circ} \mathrm{C}$, its salinity is $201 \mathrm{ppt}$, and its humidity level is $86.5 \%$; and the temperature for Rhizophora mucronata is between $30-30.2^{\circ} \mathrm{C}$, its salinity is between $20-20.5 \mathrm{ppt}$, and its humidity is $87 \%$.

\section{Discussion}

The data density of trees in the village of Torosiaje Jaya shows that sampling point 3,2 , and 1 has the highest density. This is evidenced, with 36 trees found at sampling point 3, Bruguiera gymnorrhiza is the dominant species, 35 trees for sampling point 2 with dominant species Rhizophora mucronata, and found 34 trees for one sampling point with the dominant species Rhizophora stylosa. These species were classified as dominant as they are the dominant species found at the research site and had the widest distribution over the site. 
Table 1. Density value, the density of all species per hectare, and tree volume at the research site

\begin{tabular}{|c|c|c|c|c|c|c|}
\hline Species names & TS & Quadrant & NP & $\begin{array}{c}\text { JP } \\
(\mathbf{m})\end{array}$ & $\begin{array}{c}\text { DP } \\
(\mathbf{c m})\end{array}$ & $\begin{array}{c}\mathbf{V P} \\
\left(\mathbf{m}^{\mathbf{3}}\right)\end{array}$ \\
\hline B.gymnorrhiza & 1 & I & 1 & 8 & 82 & $2,566.68$ \\
\hline B.gymnorrhiza & & & 2 & 12 & 86 & $2,826.5$ \\
\hline B.gymnorrhiza & & & 3 & 14 & 92 & $3,638.98$ \\
\hline B.gymnorrhiza & & & 4 & 18 & 102 & $4,473.06$ \\
\hline B.gymnorrhiza & & & 5 & 21 & 82 & $2,248.47$ \\
\hline B.gymnorrhiza & & & 6 & 26 & 108 & $4,457.58$ \\
\hline B.gymnorrhiza & & & 7 & 33 & 83 & $1,974.55$ \\
\hline B.gymnorrhiza & & & 8 & 42 & 85 & 2,416 \\
\hline B. gymnorrhiza & & & 9 & 49 & 74 & $1,831.15$ \\
\hline B.gymnorrhiza & & II & 10 & 8 & 72 & $1,485.86$ \\
\hline B.gymnorrhiza & & & 11 & 10 & 68 & $1,104.46$ \\
\hline B.gymnorrhiza & & & 12 & 16 & 82 & $1,927.26$ \\
\hline B.gymnorrhiza & & & 13 & 21 & 86 & $2,826.5$ \\
\hline B. gymnorrhiza & & & 14 & 26 & 72 & $1,485.86$ \\
\hline B. gymnorrhiza & & & 15 & 35 & 92 & $2,830.32$ \\
\hline B.gymnorrhiza & & & 16 & 47 & 68 & $1,104.46$ \\
\hline B.gymnorrhiza & & III & 17 & 5 & 72 & $1,485.86$ \\
\hline B.gymnorrhiza & & & 18 & 7 & 82 & $2,248.47$ \\
\hline B.gymnorrhiza & & & 19 & 12 & 85 & $2,761.15$ \\
\hline B.gymnorrhiza & & & 20 & 18 & 65 & $1,009.16$ \\
\hline B.gymnorrhiza & & & 21 & 22 & 82 & $2,248.47$ \\
\hline B.gymnorrhiza & & & 22 & 29 & 93 & $3,305.35$ \\
\hline B.gymnorrhiza & & & 23 & 35 & 100 & $3,821.66$ \\
\hline B.gymnorrhiza & & & 24 & 44 & 120 & $6,191.08$ \\
\hline B.gymnorrhiza & & IV & 25 & 6 & 75 & $1,612.26$ \\
\hline B.gymnorrhiza & & & 26 & 11 & 72 & $1,485.86$ \\
\hline B.gymnorrhiza & & & 27 & 17 & 82 & $2,248.47$ \\
\hline B.gymnorrhiza & & & 28 & 23 & 65 & $1,009.16$ \\
\hline B.gymnorrhiza & & & 29 & 32 & 83 & $2,303.65$ \\
\hline B.gymnorrhiza & & & 30 & 34 & 68 & $1,104.46$ \\
\hline B. gymnorrhiza & & & 31 & 37 & 72 & $1,485.86$ \\
\hline B.gymnorrhiza & & & 32 & 40 & 64 & 978.34 \\
\hline B.gymnorrhiza & & & 33 & 43 & 89 & $2,648.74$ \\
\hline B.gymnorrhiza & & & 34 & 49 & 93 & $3,305.35$ \\
\hline R. mucronata & 2 & I & 1 & 5 & 68 & $1,104.46$ \\
\hline R. mucronata & & & 2 & 8 & 84 & $2,022.42$ \\
\hline R. mucronata & & & 3 & 16 & 82 & $1,927.26$ \\
\hline R. mucronata & & & 4 & 19 & 65 & $1,009.16$ \\
\hline R. mucronata & & & 5 & 21 & 98 & $3,670.32$ \\
\hline R. mucronata & & & 6 & 35 & 74 & $1,569.55$ \\
\hline R. mucronata & & & 7 & 48 & 95 & $3,880.18$ \\
\hline R. mucronata & & II & 8 & 6 & 68 & $1,325.35$ \\
\hline R. mucronata & & & 9 & 9 & 75 & $1,880.97$ \\
\hline R. mucronata & & & 10 & 12 & 81 & $2,193.96$ \\
\hline R. mucronata & & & 11 & 17 & 72 & $1,485.86$ \\
\hline R. mucronata & & & 12 & 22 & 103 & $4,054.39$ \\
\hline R. mucronata & & & 13 & 28 & 102 & $4,473.06$ \\
\hline R. mucronata & & & 14 & 30 & 82 & $1,927.26$ \\
\hline R. mucronata & & & 15 & 33 & 96 & $3,081.78$ \\
\hline R. mucronata & & & 16 & 37 & 99 & $3,277.4$ \\
\hline R. mucronata & & III & 17 & 5 & 68 & $1,104.46$ \\
\hline R. mucronata & & & 18 & 9 & 69 & $1,137.18$ \\
\hline R. mucronata & & & 19 & 13 & 74 & $1,569.55$ \\
\hline R. mисronata & & & 20 & 19 & 78 & $1,743.82$ \\
\hline R. mucronata & & & 21 & 24 & 68 & $1,104.46$ \\
\hline R. mucronata & & & 22 & 28 & 75 & $1,612.26$ \\
\hline R. mucronata & & & 23 & 31 & 82 & $1,927.26$ \\
\hline R. mucronata & & & 24 & 42 & 86 & $2,119.87$ \\
\hline R. mucronata & & & 25 & 26 & 96 & $3,522.04$ \\
\hline R. mucronata & & & 26 & 37 & 106 & $3,757.26$ \\
\hline R. mucronata & & & 27 & 45 & 116 & 5.785 .22 \\
\hline R. mucronata & & IV & 28 & 7 & 98 & $3,211.53$ \\
\hline
\end{tabular}

\begin{tabular}{|c|c|c|c|c|c|c|}
\hline R. mucronata & & & 29 & 11 & 64 & 978.34 \\
\hline R. mисronata & & & 30 & 26 & 102 & $3,976.05$ \\
\hline R. mucronata & & & 31 & 30 & 68 & $1,104.46$ \\
\hline R. mucronata & & & 32 & 33 & 76 & $1,655.54$ \\
\hline R. mucronata & & & 33 & 42 & 69 & $1,364.62$ \\
\hline R. mucronata & & & 34 & 22 & 74 & $1,569.55$ \\
\hline R. mucronata & & & 35 & 35 & 82 & $1,927.26$ \\
\hline R. mucronata & 3 & I & 1 & 5 & 69 & $1,364.62$ \\
\hline R. mucronata & & & 2 & 9 & 69 & $1,137.18$ \\
\hline R. mucronata & & & 3 & 13 & 72 & $1,485.86$ \\
\hline R. mucronata & & & 4 & 17 & 74 & $1,569.55$ \\
\hline R. mисronata & & & 5 & 22 & 86 & $2,473.18$ \\
\hline B. gymnorrhiza & & & 6 & 28 & 88 & $2,589.55$ \\
\hline B. gymnorrhiza & & & 7 & 32 & 65 & $1,210.99$ \\
\hline R. apiculata & & & 8 & 38 & 66 & $1,040.45$ \\
\hline R. apiculata & & & 9 & 40 & 74 & $1,569.55$ \\
\hline R. apiculata & & & 10 & 45 & 96 & $3,522.04$ \\
\hline R. stylosa & & II & 11 & 7 & 64 & 978.34 \\
\hline R. stylosa & & & 12 & 11 & 85 & $2,070.86$ \\
\hline R. stylosa & & & 13 & 13 & 96 & $3,522.04$ \\
\hline R. stylosa & & & 14 & 20 & 103 & $4,054.39$ \\
\hline R. stylosa & & & 15 & 23 & 112 & $5,393.12$ \\
\hline R. stylosa & & & 16 & 42 & 96 & $3,522.04$ \\
\hline R. mucronata & & & 17 & 37 & 92 & $2,830.32$ \\
\hline R. mucronata & & & 18 & 31 & 88 & $2,219.62$ \\
\hline R. mucronata & & & 19 & 34 & 102 & $4,473.06$ \\
\hline R. apiculata & & III & 20 & 5 & 72 & $1,485.86$ \\
\hline R. apiculata & & & 21 & 11 & 68 & $1,104.46$ \\
\hline R. apiculata & & & 22 & 18 & 66 & $1,248.54$ \\
\hline R. apiculata & & & 23 & 24 & 89 & $3,027.13$ \\
\hline R. apiculata & & & 24 & 26 & 102 & $4,473.06$ \\
\hline R. stylosa & & & 25 & 21 & 115 & $5, .685 .91$ \\
\hline R. stylosa & & & 26 & 31 & 92 & $3,234.65$ \\
\hline R. stylosa & & & 27 & 39 & 96 & $3,522.04$ \\
\hline B. gymnorrhiza & & IV & 28 & 6 & 65 & $1,009.16$ \\
\hline B. gymnorrhiza & & & 29 & 10 & 86 & $2,119.87$ \\
\hline B. gymnorrhiza & & & 30 & 15 & 72 & $1,485.86$ \\
\hline R. stylosa & & & 31 & 24 & 68 & $1,325.35$ \\
\hline R. stylosa & & & 32 & 34 & 72 & $1,485.86$ \\
\hline R. stylosa & & & 33 & 38 & 86 & $2,119.87$ \\
\hline R. тисronata & & & 34 & 30 & 102 & $4,473.06$ \\
\hline R. mucronata & & & 35 & 21 & 64 & 978.34 \\
\hline R. mucronata & & & 36 & 48 & 121 & 8.392 .93 \\
\hline \multicolumn{3}{|c|}{ The mean distance of tree $\left(\mathrm{m}^{2}\right)$} & \multicolumn{4}{|c|}{581,94} \\
\hline \multicolumn{3}{|c|}{ The density of all species/ha } & \multicolumn{4}{|c|}{51,55} \\
\hline
\end{tabular}

Notes: TS: Sampling Point, Np: Tree Number, Jp: Tree Distance,

Dp: Tree Distance, Vp: Tree Volume

Table 2. The number of trees in sampling points $300 \mathrm{~m}^{2}$ in Mangrove Forests Torosiaje Jaya, Gorontalo, Indonesia.

\begin{tabular}{lcc}
\hline Location & $\begin{array}{c}\text { Number of } \\
\text { species }\end{array}$ & $\begin{array}{c}\text { Number of } \\
\text { trees }\end{array}$ \\
\hline Side point 1 & 1 & 34 \\
Side point 2 & 1 & 35 \\
Side point 3 & 4 & 36 \\
\hline
\end{tabular}

Data showed that the dominant species found in each Sampling Point possessed the highest adaptation skills towards their habitats for survival purposes. The species composition of coastal mangrove forests Torosiaje Jaya Village found four species of Bruguiera gymnorrhiza, 
namely, Rhizophora mucronata, Rhizophora apiculata, Rhizophora stylosa.

Salinity, substrate, and temperature affect mangrove density and species composition. Salinity affects the growth and density of mangroves, based on further research towards the sea, the salinity or salt content of the higher places. Mangrove is not a plant that needs salt, but mangrove is a plant tolerant of salt. This is in line with the opinions by Hutahaean et al. (1999), which examined the mineral elements needed for the growth of mangrove plants are the macro elements such as $\mathrm{N}, \mathrm{P}, \mathrm{S}, \mathrm{K}, \mathrm{Ca}$, and $\mathrm{Mg}$ and microelements consisting of $\mathrm{Zn}, \mathrm{Mn}$, and $\mathrm{Cu}$. Based on these results, the elements $\mathrm{Na}$ and $\mathrm{Cl}$ are not needed for the growth of mangrove plants. If the salt content on the site is too high, the growth will be stunted mangrove. According to Hutahaean et al. (1999) that the range of salinity for Rhizophora mucronata is 12-30 ppt. Based on the results of research that salinity in coastal areas Torosiaje Jaya Village for 21.5 to $22 \mathrm{ppt}$ of Rhizophora mucronata. Species, a species that is from 21.5 to $22 \mathrm{ppt}$ of Bruguiera gymnorrhiza, Rhizophora stylosa species are 20 to 21.5 ppt. Therefore, the coastal of Torosiaje Jaya Village is a coastal region that can support the growth of three species of mangrove dominance.

Various types of mangroves overcome salinity levels in different ways. Rhizophora, for instance, secretes excess salt through the glands under its leaves to overcome high salinity. The absorbed water has almost become fresh water, with $90-97 \%$ of salt content in seawater being unable to pass through this root filter. Salt from the plant body was accumulated in the old leaves and wasted along with fall leaves. Mangrove vegetation should seek to maintain water because of the difficulty in obtaining fresh water.

In addition to salinity, density substrate also affects the mangroves. The substrate is generally composed of sand, clay, and dust. Based on the laboratory analysis results, soil dominant mangrove species Bruguiera gymnorrhiza is a land with a $<5 \%$ sand, dust from 61.1 to $75.3 \%$, and 17.1 to 47.9\% clay. According to Indah et al. (2008), this ground, including clayey loam soil, is dominated by a blend of silt and clay that causes the formation of good texture. That is why the substrate in this region is classified as good and supports the growth of various mangrove species found in the research site.

Based on observations of air temperature at the study site ranged from $30-31.8^{\circ} \mathrm{C}$. At the point of observation that high temperature caused by sunlight is still hindered by the mangrove canopy cover so that the temperature becomes lower. Temperatures in the coastal mangrove forests Torosiaje Jaya Village is the range of temperature that supports mangrove growth. This is confirmed by Kusmana
(2010) states that if the temperature is higher than $35^{\circ} \mathrm{C}$, it will have an unfavorable influence on the process of photosynthesis, so that the process of mangrove growth will be hampered.

In conclusion, the value density types of mangrove forests in the coastal regions of Torosiaje Jaya Village for the entire species is 51.55 trees/ha with an average distance of $581.94 \mathrm{~m} /$ tree. The species composition of coastal mangrove forests of Torosiaje Jaya Village found four species, namely Bruguiera gymnorrhiza, Rhizophora mucronata, Rhizophora apiculata, and Rhizophora stylosa. Mangrove density and species composition in an area are influenced by several factors: salinity, substrate, and temperature. Habitat that affects the growth of mangrove species on the coast of Torosiaje village is mangrove soil which contains sand $(<5 \%)$, dust $(61.1-75.3 \%)$, and clay (17.1-47.9\%). The soil includes clay because dust and clay form a good texture. Therefore, the substrate found on this coast is classified as good and can support the growth of various mangrove species found in the research site.

\section{REFERENCES}

Bengen DG. 2002. Recognition \& Management of Mangrove Ecosystems. Institut Pertanian Bogor, Bogor, Indonesia.

Brown S. 1997. Estimating Biomass and Biomass Change of Tropical Forests: A Primer. UN FAO Forestry Paper 134. Food and Agriculture Organization, Rome.

Damanik R, Djamaludin R. 2012. Atlas Mangrove Teluk Tomini. Sustainable Coastal Livelihoods and Management Program, Gorontalo, Indonesia.

Dharmawan IWS, Siregar CA. 2008. Soil carbon and carbon estimation on stand of Avicennia marina (Forsk.) Vierh. in Ciasem, Purwakarta. Jurnal Penelitian Hutan dan Konservasi Alam 5 (4): 317-328. DOI: 10.20886/jphka.2008.5.4.317-328. [Indonesian]

Giesen W, Wulffraat S, Zieren M, Scholten L. 2006. Mangrove Guidebook for Southeast Asia. Food and Agriculture Organization of the United Nations Regional Office for Asia and the Pacific, Bangkok, Thailand.

Hairiah K, Rahayu S. 2007. Measurement of Stored Carbon in Various Land Use. World Agroforestry Center, Bogor. [Indonesian]

Hutahaean E, Kusmana C, Dewi RH. 1999. Study on growth capability of mangrove forest seedling of Rhizophora mucronata, Bruguiera gymnorrhiza, and Avicennia marina species on various levels of salinity. Jurnal Manajemen Hutan Tropika 5 (1): 77-85. [Indonesian]

Indah R, Jabarsyah A, Laga A. 2008. Differences in Substrate and Distribution of Mangrove Species (Case study: Mangrove Forest in the town of Tarakan). Universitas Borneo, Tarakan. [Indonesian]

Indriyanto. 2010. Forest Ecology. Bumi Aksara, Jakarta. [Indonesian]

Kusmana C. 2010. Mangrove responses towards the global climate change: The biological and ecological aspects of mangrove. Institut Pertanian Bogor, Bogor. [Indonesian]

Nugraha Y. 2011. Potential Stored Carbon in City Park 1 Bumi Serpong Damai (BSD), Serpong, Tangerang Selatan, Banten. [Hon. Thesis]. Universitas Islam Negeri Syarif Hidayatullah, Jakarta. [Indonesian]

Tomlinson PB. 1986. The Botany of Mangroves. Cambridge University Press, London. 